\title{
ZBIGNIEW ŁEPKO
}

Instytut Ekologii i Bioetyki, UKSW, Warszawa

\section{W sprawie techniki dla zrównoważonego rozwoju}

Słowa kluczowe: człowiek, technika, przyroda, zrównoważony rozwój

Keywords: man, technique, nature, sustainable development

\section{Wprowadzenie}

Problematyka techniczno-technologicznej ekspansji człowieka w przyrodzie wyznacza jeden $\mathrm{z}$ głównych wątków współczesnej debaty ekologicznej. Ukazuje ona nieprzezwyciężalną w punkcie wyjścia konfrontację radykalnie zantagonizowanych stanowisk jej uczestników. Radykalni krytycy techniki z góry odrzucali bowiem współczesny system techniczno przemysłowy i stawiali na tzw. technikę alternatywną. Przy jej pomocy miałyby się spełnić romantyczne marzenia o harmonijnej relacji człowieka do przyrody (Kiepas 1992: 77-85). Radykalni propagatorzy współczesnego systemu techniczno-przemysłowego reprezentowali zaś naiwną wiarę $\mathrm{w}$ nieograniczony postęp naukowo-techniczny. Byli bowiem przekonani, że jedynie nowoczesna technika stwarza gwarancje dobrostanu aktualnych i przyszłych pokoleń ludzkich w świecie (Ropohl 1985: 9-16).

Z czasem tak zarysowaną debatę ekologiczną wzbogaciło odwołanie się do idei zrównoważonego rozwoju. Podpowiada ona bowiem poszukiwanie nowoczesnych rozwiązań w zakresie techniczno-technologicznej obecności człowieka w przyrodzie. Celem powinno być właśnie odnalezienie zrównoważonej z wymaganiami przyrody drogi rozwoju cywilizacji technicznej. Stąd też domaga się ona z jednej strony krytycznego wskazania na słabości uproszczonej krytyki technicznej działal- 
ności człowieka w przyrodzie, z drugiej zaś strony wsparcia rozważnie krytycznego podejścia do techniki, zgodnie z którym wskazywanie na pozytywne jej skutki nie zamyka oczu na jej braki. Faktycznie bowiem technika jest niedoskonała; wymaga więc udoskonalenia poprzez ekologiczne wzmocnienie jej zdolności do dalszego rozwoju. Günther Ropohl mówi w tym przypadku o konieczności ekologicznego instalowania techniki w przyrodzie, edukacji technologicznej i adekwatnej politycznie organizacji społeczeństwa (Ropolh 1985: 9-16). Zgodnie z tym podejściem współczesna odpowiedź na wyzwania ekologiczne, poniekąd paradoksalnie, nie brzmi więc „mniej techniki”, lecz „więcej techniki”. To zaś wiąże się ściśle z wymaganiem poszukiwania odpowiedzi na pytanie sformułowane w perspektywie holistycznego myślenia o przyrodzie w nauce i gospodarce: „Co powinniśmy wiedzieć, abyśmy przy pomocy nauki i techniki mogli rozwiązywać problemy, których nie mielibyśmy bez nauki i techniki” (Meyer-Abich 1997: 10).

\section{Techniczne okowy przyrody}

Technika jest tworem człowieka dla człowieka. Tworzona z myślą o pomyślności człowieka, od początku stanowiła zarazem szczególną formę jego konfrontacji z przyrodą, prowadzącą do jej degradacji. Dzisiaj już wiadomo, że w trakcie starań o wsparte techniką zabezpieczenie pomyślności człowieka zapomniano o bezwzględnej konieczności podtrzymania w przyrodzie naturalnych procesów życia, od których ostatecznie zależy zarówno przetrwanie samej przyrody, jak i obecnego w niej człowieka. Dzisiaj już wiemy, że „przyroda nie wytrzyma każdej ingerencji człowieka i nie jest w stanie sama zaleczyć wszystkich zadanych jej ran. Cywilizacyjna presja człowieka ujawniła prawdę o przyrodzie jako delikatnej sieci życia. Nie jest więc ona stabilnym systemem, trwale zabezpieczonym przed każdą ingerencją człowieka. Przyroda jest bardziej wrażliwa niż sądziliśmy, a życie biologiczne bardziej narażone na zniszczenie niż myśleliśmy. Gdzie bowiem niegdyś gwałt przyrody zagrażał człowiekowi, tam dzisiaj gwałt człowieka zagraża przyrodzie". (Łepko 2003: 83-84). 
Szczególne nasilenie gwałtownej i głębokiej ingerencji człowieka w przyrodę zapoczątkowało nowożytne sprzęgnięcie nauki z techniką. Można powiedzieć, że odtąd nauka radykalnie zerwała ze starożytną i średniowieczną strategią badania przyrody. Wprawdzie w epokach przednowożytnych uczeni korzystali z takich metod badawczych, jak obserwacja i matematyczny opis przyrody, to jednak nie przeprowadzali oni jeszcze eksperymentów kontrolowanych (Dusek 2011: 42-43). Podczas gdy w epoce starożytnej i średniowiecznej poznanie przyrody stanowiło cel sam w sobie, albo sposób poznania Boga czy wyraz szczególnej czci oddawanej Bogu, w epoce nowożytnej zostało ono uznane za środek w dążeniu do wzrostu powszechnego dobrobytu ludzkości. Tym samym nauka stała się głównym narzędziem w rękach człowieka, który nie tylko może opanowywać, ale i zmieniać otaczający go świat (Łepko 1998: 53).

Wiele wskazuje na to, że podstawowym warunkiem naukowo-technicznej przemiany świata był fakt, iż od początku nowożytności nauka była uprawiana, rozwijana, organizowana i finansowana jako środek wspomagający ekspansję człowieka w jego przyrodniczym środowisku naturalnym. Nic więc dziwnego, że wraz z każdym sukcesem na tym polu, wzrastał także społeczny autorytet nauki. Swój społeczny awans nauka nowożytna zawdzięcza zatem głównie swej efektywności praktycznej, mniej zaś splendorowi swych teorii. Oznacza to, że uznawany w nowożytności wysoki autorytet nauki jest efektem jej wewnętrznego sprzężenia $\mathrm{z}$ techniką. Sprzężenie to wyraża więc istotną cechę nauki nowożytnej, która polega na tym, że zdobyta przez nią wiedza nie tylko może być praktycznie wykorzystywana, lecz że jej techniczna stosowalność istotnie dopełnia i ostatecznie spełnia zlecone jej zadanie. Ta istotna cecha nauki nowożytnej domyka jej charakterystykę metodologiczną, do której przynależy najpierw typ udzielanych przez nią wyjaśnień, a następnie wykorzystywana przez nią eksperymentalna metoda dochodzenia do prawdy o rzeczywistości (Hałaczek 1994: 130).

Opracowania z zakresu historii nauki nowożytnej prezentują jej wewnętrzną dynamikę, prowadzącą do rozszerzania jej wpływów na różne obszary działalności człowieka. Wymowną tego ilustracją jest odnotowana w dziejach kultury europejskiej kolejność powstawania realnych 
nauk szczegółowych, a więc takich, w obrębie których wartość teorii mierzona jest jej zdatnością do stechnologizowania. Odnośne opracowania wskazują kolejno na mechanikę, chemię, elektrodynamikę, fizykę jądrową i biotechnologię. Opracowania te podkreślają, że nauka wtedy jest dojrzała do stechnologizowania, gdy spełnia wymagania stawiane jej przez Galileusza, tzn., gdy na drodze, którą nazywa on via resolutiva, a więc na drodze postępowania analitycznego, osiągnie taki etap, który umożliwia jej wejście na via compositiva, a więc na drogę syntetyzowania cząstkowych i skwantyfikowanych elementów badanego przedmiotu. Hans Jonas uważa, że dzisiaj ten etap osiągnęła także biologia. Chodzi mianowicie o biologię molekularną, która stwarza możliwości powiązania via resolutiva i via compsitiva w odniesieniu do przyrody ożywionej (Jonas 1990: 30-40).

Fakt ten wskazuje na wzrastające możliwości człowieka w zakresie coraz głębszych ingerencji w przyrodę ożywioną. Potwierdza zarazem istnienie coraz silniejszej presji cywilizacyjnej wywieranej na człowieka w celu zrealizowania swoich potencjalnych możliwości w tym względzie. Jonas podkreśla w związku z tym, że poznawcze wkraczanie w tajemnice przyrody jest już dzisiaj faktycznie manipulowaniem przyrodą (Jonas 1981: 434-439).

Zarazem obserwuje się zjawisko dialektycznej roli nowożytnej techniki w procesie ludzkiego opanowywania przyrody (Łepko 2003: 134-139). $\mathrm{Z}$ jednej strony bowiem technika dowodzi przewagi człowieka nad przyrodą, z drugiej zaś strony coraz ściślej wiąże go ze sobą i nierzadko podporządkowuje go sobie; na skutek łatwej dostępności techniki potrzeby człowieka wzrastają bowiem wprost proporcjonalnie do technicznych możliwości ich zaspokojenia. W ten sposób dążenie człowieka do technicznego panowania nad przyrodą pociąga za sobą jego samopodporządkowanie się technice. Trafnie wyraził to Martin Heidegger, gdy już ponad pół wieku temu pisał: „Niepostrzeżenie zostaliśmy tak mocno przykuci do przedmiotów technicznych, że popadliśmy wobec nich w zależność niewolniczą." (Heidegger 1959: 24-25) Wyrazem tak rozumianej niewolniczej zależności człowieka od techniki jest łatwo zauważalny dzisiaj fakt generowania przez technikę coraz większych potrzeb człowieka. Znawcy przedmiotu mówią w tym 
przypadku o „metapotrzebach” człowieka i mają na myśli takie potrzeby, których zaspokojenie wymusza stosowanie coraz to nowszej techniki i technologii (Hösle 1991: 60). W ten sposób wyraża się infinityzm nauki nowożytnej; w odróżnieniu od nauki przednowożytnej rozwija się ona w kierunku wyznaczanym przez swoją własną potencjalność. Oznacza to, że nierozerwalnie związana z techniką nauka nowożytna coraz bardziej opanowuje zarówno przyrodę, jak i żyjącego w niej człowieka. Ta samowzmacniająca się dynamika rozwoju nauki nowożytnej określa taki stan kultury europejskiej, w którym Vittorio Hösle za Arnoldem Gehlenem dostrzega ,jedną z przyczyn coraz słabszej zdolności polityki do reagowania na kryzys ekologiczny" (Hösle 1991: 60).

Wskazana tutaj dialektyczna funkcja nauki nowożytnej, zgodnie z którą dążenie człowieka do naukowo-technicznego panowania nad przyrodą prowadzi do niewolniczego poddania się samego człowieka technice, wskazuje na ścisły związek przyrodniczego i antropologicznego wymiaru skutków jej technicznego zastosowania. Oznacza to, że skutki te dotyczą nie tylko systemów biologicznych, lecz również ludzkich systemów społecznych. Wystarczy wspomnieć choćby o skutkach globalnego stosowania środków antykoncepcyjnych, oddziaływania środków społecznego przekazu czy środków masowego zagłady. Spowodowane nimi rewolucyjne zmiany w zakresie obyczajowości, komunikacji społecznej, postrzegania rzeczywistości wojny i politycznych relacji międzypaństwowych uwyraźniły problem swoistej „technologii panowania nad masami” (Anders 1956: 235-294; Anders 1980: 58-79 i 210-247). Stanowi ona kompleksowy wyraz funkcjonowania takiego porządku społecznego, do którego Konrad Lorenz odniósł nazwę „system technokratyczny”, czyli taki system, który niesie ze sobą groźbę „rozpanoszenia się techniki w charakterze tyrana ludzkości” (Lorenz 1986: 145). W tym przypadku chodzi o ostrzeżenie przed samowładnym funkcjonowaniem tzw. „wielkiej techniki”, która swoją nieprzenikliwością, centralizmem i niepohamowanym wzrostem gwałtownie przekracza ludzką miarę i przejmuje totalne panowanie nad człowiekiem i właściwymi mu formami życia. W tej sytuacji nie dziwi przestroga przed rzeczywistym złem, którym jest „ujawniająca się tendencja ludzkości do kulturowego i, być może, genetycznego roz- 
woju w kierunku szczęśliwego robota, który najlepiej przystosowany jest do życia w maksymalnie zindustrializowanym systemie społecznym" (Evans 1977: 111).

Zdaniem Konrada Lorenza stało się tak w wyniku zaburzenia porządku przyczynowo-skutkowego w procesie naukowego wspierania nowożytnego dążenia ludzkości do przezwyciężenia zagrażających jej chorób i różnych odmian biedy materialnej: „Pewna działalność, która zgodnie ze swą istotą miała być środkiem do celu, stała się celem samym w sobie. Gałęzie wiedzy, które stanowią podłoże techniki, są przeceniane, a niedoceniane jest znaczenie wszystkich innych" (Lorenz 1986: 145). Taki stan rzeczy jest wynikiem zainicjowanego w epoce nowożytnej procesu wzajemnego oddziaływania między technokracją a scjentyzmem. W epoce nowożytnej mamy bowiem do czynienia z przybierającym na sile zjawiskiem absolutyzowania nauki obiektywistycznej. Jego apogeum zdaje się zaś wyrażać swoisty totalitaryzm przyrodoznawczy, zgodnie z którym wszystkie pytania, istotne dla człowieka, dadzą się sprowadzić do pytań przyczynowo-skutkowych. Nowożytne przeświadczenie o trafności tak rozumianej redukcji kondycji człowieka i jego odniesień do właściwej mu naturalnej (przyrodniczej) przestrzeni życia niechybnie musi prowadzić zarówno do uprzedmiotowienia przyrody, jak i obecnego w niej człowieka, ze wszystkimi tego negatywnymi konsekwencjami (Łepko 2010b: 129).

\section{Ekologiczna ocena i wartościowanie techniki}

Nowoczesna technika jest niedoskonała o tyle, o ile brakuje jej ekologicznej instalacji w przyrodzie. Współcześni znawcy tej problematyki postulują wobec tego, aby została ona poddana kolejno procedurze oceny i wartościowania ekologicznego (Kiepas 2006: 77-86). Procedura oceny ekologicznej jest niejako dwuetapowa: pierwszy etap dotyczy rejestru faktycznych następstw stosowania techniki w przyrodzie, drugi etap dotyczy zaś oceny ze względu na wykorzystanie możliwości i związanego z nimi ryzyka jej zastosowania. Tak rozumianą procedurę oceny techniki dopełnia procedura jej ekologicznego wartościowania według miar prawnych i etycznych. Oczekiwanym efektem tych proce- 
dur miałyby być przyjazne dla środowiska naturalnego bezpośrednie i uboczne skutki prowadzonych w nim działań techniczno-technologicznych (Ropohl 1996).

Wskazane tutaj procedury ekologicznej oceny stosowania techniki $\mathrm{w}$ przyrodzie stanowią prace badawcze prowadzone $\mathrm{z}$ uwzględnieniem standardów objętych określeniem technology assessment (TA). Wyraża ono koncepcje opartego na krytycznym podejściu do techniki politycznego sterowania rozwojem technicznym. Koncepcje te były przedmiotem żywych dyskusji w Stanach Zjednoczonych Ameryki Północnej mniej więcej od połowy lat sześćdziesiątych ubiegłego stulecia. Ich efektem stało się zaś utworzenie w 1973 r. przy Kongresie Amerykańskim Office of Technology Assessment (OTA), czyli parlamentarnej instytucji doradztwa naukowego $\mathrm{w}$ zakresie wykorzystania techniki i technologii. Niedługo potem parlamenty innych krajów powoływały do istnienia wzorowane na doświadczeniach amerykańskich instytucje doradztwa naukowego w zakresie wspieranej techniką działalności człowieka w przyrodzie. Z czasem konieczność prac nad ekologicznym wartościowaniem techniki zaczęli dostrzegać przedstawiciele przedsiębiorstw gospodarczych, a w dalszej kolejności instytutów akademickich. Dzisiaj zaś stały się one przedmiotem dyskursu publicznego: ostatecznie chodzi bowiem o to, aby upowszechnić wiedzę na ten temat i w dyskusję nad nim zaangażować jak najszersze kręgi społeczeństw państw wysoko rozwiniętych. Tutaj jest także miejsce dla każdego, kto chce rozpoznać i wyrazić swój osobisty stosunek do techniki i kto chciałby otrzymać wskazania odnośnie do wspieranych techniką własnych działań w przyrodniczym środowisku naturalnym (Ropohl, Hubig 1994: 7-17).

Zarówno instytucjonalne, jak i osobowe zaangażowanie w procedury objęte określeniem technology assessment dotyczy postępowania według struktury dwuetapowej oceny i dopełniającego je ekologicznego wartościowania techniki. W przypadku pierwszego etapu oceny chodzi o konieczność oszacowania następstw technicznej działalności człowieka w przyrodzie. Tutaj należy więc uwzględnić pytanie, na podstawie jakiej wiedzy możemy te następstwa zdiagnozować, czyli roz- 
patrzyć prawdopodobne pożytki i prawdopodobne szkody stosowania techniki w przyrodzie (Ropohl, Hubig 1994: 7-17).

Równocześnie chodzi o to, aby we wskazanym tutaj zakresie wypracować merytorycznie pogłębiony i jak najszerszy konsensus ekspertów, reprezentujących zróżnicowane metody pracy (Jelden 1995: 4-32). Na szczególną uwagę w tym względzie zasługują więc oceny dokonywane już na etapie innowacyjnego wdrażania wynalazków technicznych. Obowiązuje tutaj udokumentowana historycznie szczegółowa dyrektywa, zgodnie z którą nie powinno się czekać, aż określona technika osiągnie etap wysokiego rozwoju, lecz już na pierwszym etapie jej rozwoju i w odniesieniu do konkretnych przedsięwzięć prototypowych należy dokonywać jej oceny z uwzględnieniem jak najszerszego spektrum zróżnicowanych punktów odniesienia. Zgodnie z tą dyrektywą podstawami oceny techniki są szacunkowe rejestracje technicznych, ekonomicznych, kulturalnych, społecznych i ekologicznych następstw określonej innowacji technicznej. Wychodzi się bowiem z założenia, że przy uwzględnieniu odpowiednio szerokiego horyzontu obserwacyjnego możliwa jest jednostkowa ocena tych następstw i tym samym możliwe staje się dojście do normatywnie ugruntowanych rozstrzygnięć. Należy przy tym pamiętać, że tak rozumiana ocena techniki może być jedynie instrumentem pomocniczym w dochodzeniu do rozsądnych rozstrzygnięć. $W$ takim mianowicie stopniu, w jakim stanowi ona intelektualną zachętę do krytycznej dyskusji i ostatecznie prowadzi do podejmowania trafnych politycznie rozstrzygnięć (König, Rapp 1994: 1-38).

$\mathrm{Na}$ drugim etapie oceny techniki dokonuje się identyfikacja i specyfikacja wiedzy zdobytej na pierwszym etapie. Dokonuje się ona zgodnie z pytaniami o szansę albo ryzyko związane z funkcjonowaniem ocenianego obiektu technicznego i procedury technologicznej. Tak ogólnie sformułowane pytania w trakcie prac badawczych są uszczegółowiane w formie pytań, dotyczących np. stopniowania spodziewanych pożytków, osiąganych dzięki stosowaniu określonych narzędzi technicznych. Szczegółowe pytania dotyczą także zakresu tolerancji wobec określonego ryzyka zastosowania narzędzi czy metod technicznego działania $\mathrm{w}$ przyrodzie. Są to wreszcie pytania o relacje korzyści i ryzyka 
z uwzględnieniem sprawiedliwości w odniesieniu do różnych podmiotów (Ropohl, Hubig 1994: 11).

Wszystkie te pytania zmierzają do tego, aby określony stan rzeczy, rozpoznany na pierwszym etapie oceny techniki, uporządkować i skatalogować według określonych kryteriów. Takie działanie dokonuje się $\mathrm{w}$ analogii do podejmowanej przez prawnika procedury ustalania faktycznego stanu rzeczy w zakresie przestępstwa i rozstrzygania o zakresie winy jego sprawcy. Można też je przyrównać do prób subtelnego charakteryzowania określonych zdobyczy jako osiągnięć zasługujących na uznanie, efektów szczęśliwych zbiegów okoliczności czy korzystnych zrządzeń losu. W dążeniu do ekologicznego instalowania techniki w przyrodzie uporządkowana wiedza na temat następstw funkcjonowania techniki stwarza możliwość jej ekologicznego wartościowania (Ropohl, Hubig 1994: 11).

Kryteriów wartościowania techniki dostarcza utrwalony system prawa stosowanego. Należy przy tym zauważyć, że taką relatywnie jednoznaczną miarą wartościowania dysponujemy w odniesieniu do posługiwania się techniką jedynie w przypadkach ekstremalnych, a więc związanych ze szkodami i wypadkami. Oznacza to, że prawne miary ekologicznego wartościowania techniki mają zastosowanie ograniczone w całościowym obszarze jej planowania i kształtowania, jej stosowania i rozstrzygania o zakupie narzędzi i aparatów technicznych. Istnieje bowiem rozległy i nieobjęty prawem taki obszar funkcjonowania techniki, na którym inne reguły stanowią kryteria naszego działania. Są to reguły etyczne, stanowiące różne wersje odpowiedzi na pytanie: „Co powinniśmy czynić”? W kontekście ekologicznego wartościowania techniki takie reguły stanowią zaś różne wersje odpowiedzi na pytanie: "Jak powinniśmy obchodzić się z techniką"? Konkretnie chodzi więc o odpowiedzi na pytania szczegółowe, dotyczące kształtowania, nabywania czy różnorodnego wykorzystywania techniki (Ropohl, Hubig 1994: 11-12; Kiepas 2006: 77-86)).

Na tym etapie wartościowania techniki prace specjalistów organizuje etyczna kategoria odpowiedzialności, czyli odwołująca się do kwalifikacji moralnych i wsparta refleksją etyczną ludzka zdolność do przewidywania dalekosiężnych skutków aktualnych działań. Przede 
wszystkim domaga się ona interdyscyplinarnego podejścia do samej techniki i całego systemu cywilizacji techniczno-technologicznej. W jego ramach wskazuje się na konieczność współpracy przyrodników, inżynierów, planistów, techników, polityków, socjologów i filozofów. Szczególna rola przypada tutaj właśnie filozofom, od których oczekuje się wyjścia z utrwalonej tradycją wieży z kości słoniowej i skonfrontowania się ze zorientowanymi na przyszłość problemami i wyzwaniami społecznymi, politycznymi, naukowymi, technicznymi i gospodarczymi (Hubig, Lenk 1994: 1-33).

Znawcy tej problematyki podkreślają, że w tym przypadku filozofia, zgodnie z tradycją sokratejską, musi stać się instancją krytyczną, inspirującą i podtrzymującą dyskurs publiczny, przez konfrontację prowadzącą do kooperacji na różnych obszarach życia publicznego, począwszy od kształcenia i wychowania młodzieży po szeroko rozumianą działalność polityczną. Najtrudniejszym zadaniem filozofii w tym zakresie wydaje się być wskazanie możliwości praktycznego spożytkowania idei zawartych w ekologicznym wartościowaniu techniki. Pełny wyraz znajduje to $\mathrm{w}$ formułowaniu pytań praktycznych, w szczególności pytań o odpowiedzialność za działania wspierane techniką i odpowiedzialność za tworzenie określonych narzędzi technicznych. Wobec ścierających się dzisiaj zróżnicowanych stanowisk etycznych, zachodzi konieczność wypracowania zasad, na podstawie których można podjąć próby uzgadniania stanowisk w palących kwestiach zastosowania techniki i kierunku rozwoju cywilizacji technicznej. W połowie lat dziewięćdziesiątych ubiegłego stulecia wskazano na szereg takich zasad, które można sprowadzić do czterech głównych (Hubig, Lenk 1994: 1-33):

- zasada utrzymania dobrobytu dla wszystkich ludzi w sprawiedliwym społeczeństwie obywatelskim;

- zasada prawnie usankcjonowanych podstaw wolnego handlu;

- zasada nienaruszalnej godności człowieka;

- zasada zachowania przyrody jako warunku życia w dobrobycie, wolności i godności.

Wprawdzie ustalenie tych zasad nie kończy procedury ekologicznego wartościowania techniki, to jednak stanowi konieczny warunek sys- 
tematycznej refleksji nad możliwością ich przyporządkowywania do określonego problemu praktycznego w celu znalezienia jego rozwiązania. Oznacza to, że etyczne podejście do techniki kształtuje się pośród kontrowersji wokół przyporządkowywania konkretnej kwestii technicznej odpowiedniej zasadzie etycznej (Hubig, Lenk 1994: 1-33).

Te kontrowersje dochodzą do głosu w trakcie analizowania kwestii odpowiedzialności. Pokazuje ono, że przezwyciężenie realnych problemów domaga się pewnej relatywizacji zasady odpowiedzialności jednostkowej. Z dobrze uzasadnionej perspektywy filozoficznej wymaga się, aby jednostka podążała za swoją odpowiedzialnością niejako okrężną drogą: poprzez zaangażowanie się w działalność instytucji i organizacji. Tylko wówczas jednostka jest w stanie rozszerzyć podstawy swojej wiedzy i skutecznego wpływania na decyzje inspirowane odpowiedzialnością. Tylko wtedy też jest ona w stanie zrealizować deklaracje odnośnie do odpowiedzialności za swoją techniczną działalność we właściwym sobie przyrodniczym środowisku życia (Hubig, Lenk 1994: 1-33).

\section{Ekologiczne przystosowanie techniki do przyrody}

Zwieńczeniem procedury ekologicznej oceny i wartościowania techniki są prace nad jej przystosowaniem do przyrody. Przedmiotowe opracowania tej problematyki postulują, aby bezpośrednie zaangażowanie $\mathrm{w}$ te prace stanowiło jedno z głównych zadań polityki poszczególnych państw narodowych, regionów czy takich struktur ponadnarodowych, jak np. Unia Europejska. Opracowania te podkreślają, że choć państwowe wysiłki na rzecz unikania niechcianych następstw stosowania techniki znane są już przynajmniej od średniowiecza (Mieck 1967: 36-78), to jednak dzisiaj, z oczywistych poniekąd racji, nabierają one szczególnego znaczenia. Ich ranga wynika bowiem $\mathrm{z}$ radykalnie nowych jakości naukowo-technicznego rozwoju w ramach procesu intensywnej industrializacji. Dlatego też decydenci polityczni powinni zasięgać doradczych opinii kompetentnych naukowców i techników. Dopiero wówczas mogą podejmować odpowiedzialne decyzje w zakresie inicjo- 
wania procedury ekologicznej oceny i wartościowania techniki, a także jej organizowania i zarządzania nią (Bugl, Mai 1994: 4-37).

W tej perspektywie ekologiczna ocena i wartościowanie techniki jest dopełniana decyzjami w zakresie ekologicznego kształtowania techniki. Z politycznego punktu widzenia wyzwaniem staje się nie tylko sama technika jako zjawisko cywilizacyjne, lecz również jej społeczne otoczenie. Chodzi bowiem o to, aby kształtowanie techniki stało się zadaniem ogólnospołecznym. Wówczas decyzje odnośnie do stosowania określonych instrumentów politycznych do kształtowania techniki uzyskują także legitymizację demokratyczną; takie decyzje skutkują pozytywnie w przestrzeni stworzonej przez relacje społeczeństwa dysponującego opinią publiczną z parlamentem dysponującym energią legislacyjną wspartą doradztwem merytorycznym ekspertów. W takiej przestrzeni demokratycznej rozstrzygnięcia polityczne decydentów mogą ponadto sprzyjać pogodzeniu zróżnicowanych interesów podmiotów zainteresowanych funkcjonowaniem techniki w przyrodzie (Bugl, Mai 1994: 4-37).

Zaangażowanie polityczne w prace nad ekologicznym instalowaniem techniki w przyrodzie wpływa na zmianę dotychczasowej perspektywy postrzegania i rozumienia techniki. Ropohl zauważa w związku z tym, że długo była ona niewłaściwie rozumiana jako prywatna sprawa wynalazców i przedsiębiorców. Faktycznie zaś procesy techniczno-technologiczne tak rozlegle i tak głęboko wkraczają w świat pracy i w prywatne życie poszczególnych osób, że technika stała się realną siłą kształtowania spraw społeczno-politycznych. Techniczne nowości wpływają nie tylko na rynek pracy, lecz również na kwalifikacje zawodowe i systemy kształcenia; tym samym kształtują prywatną codzienność poszczególnych osób i ich wzajemne relacje w życiu społecznym. Oznacza to, że nowości techniczne wywołują zarówno zmiany gospodarcze, jak i społeczne. W ten sposób dysponują niejako władzą, którą można porównawczo odnieść do władzy politycznej. Jeśli więc władza polityczna powinna być legitymowana demokratycznie, to przemieniające świat siły techniki wymagałyby także adekwatnych form kontroli społecznej (Ropohl 1985: 156-179). 
Uwzględnia się przy tym fakt, że technika stanowi wyraz określonej formacji cywilizacyjnej, która nie ogranicza się jedynie do funkcjonowania sztucznie wytworzonych przedmiotów. Maszyny, aparaty i narzędzia właściwy sens uzyskują dopiero w kontekście antropologicznym, a więc wtedy, gdy ludzie ich używają i w akcie stosowania wchodzą z nimi w różne relacje, aż po ścisłą jedność współdziałania. Oznacza to, że technika każdorazowo musi być niejako zestrojona z cielesnymi, psychicznymi i duchowymi zdolnościami i potrzebami jednostek. To zaś stanowi inspirację do refleksji nad koniecznymi warunkami zachowania właściwej człowiekowi suwerenności względem techniki i technologii. Przede wszystkim jednak technika wymusza osobistą kompetencję użytkownika, która musi sprostać potędze przedmiotów technicznych. Kompetencja osobista oznacza nie tylko możliwość sprawnego obsługiwania przedmiotów technicznych, lecz także zdolność analitycznego rozumienia ich funkcji i budowy. Oznacza ponadto zdolność dokonywania przemyślanego ich zakupu, wreszcie samodzielnie dokonywanych konserwacji i napraw. Szczególnie ważna jest zaś zdolność do przewidywania skutków celowego stosowania urządzeń technicznych w środowisku naturalnym. Zdaniem G. Ropohla, bez tych kompetencji w zakresie użytkowania techniki, pozostaje ona jedynie niedoskonałym dziełem sztuki (Ropohl 1985: 134-156).

Powodowany względami ekologicznymi przyszłościowy rozwój techniki musi być kształtowany w sposób planowy i świadomy. Domaga się więc uzupełnienia jej o to, czego jej jeszcze dzisiaj w znacznej mierze brakuje: ekologicznego umieszczenia w przyrodzie, technologicznego uświadomienia obywateli i adekwatnej organizacji społeczeństwa (Brennecke, Poser, Garbe, Schröter 1995: 4-46). W zapleczu tych działań znajduje się więc takie rozumienie techniki, które nie ogranicza się do produktów pracy inżynierów. Stanowi ona bowiem także swoiste spoiwo systemu społecznego, w obrębie którego narzędzia techniczne powstają i są stosowane.

Wskazane tutaj uwarunkowania rozwoju techniki korespondują z postulatem nauki dla zrównoważonego rozwoju. Najczęściej pojawia się on w kontekście rozważań nad kulturową historią przyrody ze szczególnym uwzględnieniem holistycznego myślenia o przyrodzie 
w nauce i gospodarce. Oznacza to odwoływanie się do wartościowania zgodnie z ideałami poznawczymi, wyznaczającymi holistyczną perspektywę ujmowania prawdy o rzeczywistości. Ostatecznie idzie więc o przezwyciężenie nowożytnej tradycji naukowo-technicznej. Jego efektem miałoby być zapoczątkowanie tradycji, w ramach której wiodące poznawczo jest uczucie szacunku dla życia. Ono miałoby konstytuować naukę, dla której warta zdobycia jest tylko ta wiedza, która sprzyja pokojowemu współistnieniu człowieka z przyrodą pozaludzką (Łepko 2010a: 77-86).

Tak rozumiany pokój człowieka z przyrodą zabezpiecza przyszłość społeczeństwa industrialnego i najbardziej dojrzałą postać osiąga poprzez uzgadnianie praw gospodarczych z prawami przyrody. Stąd od jakiegoś czasu ponawiany jest postulat, aby ekonomię, czyli naukę o gospodarowaniu człowieka uprawiać jako ekologię gatunku Homo sapiens. Tak rozumiana ekonomia miałaby nosić nazwę „ekologia humanistyczna” i stanowiłaby istotny element całościowej wiedzy o związkach ludzkiego życia z przyrodą pozaludzką. Zgodnie z tym ujęciem, holistyczna perspektywa przyszłościowej nauki o miejscu i roli człowieka w przyrodzie warunkuje utrzymanie holistycznej perspektywy ludzkiego gospodarowania w przyrodzie. Nauką, sprzyjającą ekologicznej instalacji techniki w przyrodzie jest tylko ta wiedza, która sprzyja naturalnemu współistnieniu człowieka z przyrodą pozaludzką (Drieschner 1997: 337-356). Z tej racji na znaczeniu zyskują liczne projekty surowcowo i energetycznie oszczędnej produkcji, dopełniane projektami tworzenia techniki sortującej i przetwarzającej odpady na surowce wtórne. W tym sensie odpowiedź na wyzwania ekologiczne nie brzmi dzisiaj: mniej techniki, lecz więcej techniki, włączonej w kompleksowo zorganizowany system gospodarki efektywnej, czyli takiej, w ramach której dąży się do wzrostu wydajności pracy przy równoczesnym zmniejszeniu nakładu zasobów naturalnych (Weizsäcker 1999: 55-75).

Za takim modelem rozwoju gospodarczego musi podążać rozwój naukowo-techniczny, warunkowany wymaganiami politycznymi i etycznymi (Kiepas 2006: 77-86). W szczególności nowe zadania inżynierskie stoją przed techniką środowiskową. Na szczególną uwagę 
zasługują więc nowe techniki pozyskiwania surowców i energii, skuteczne urządzenia techniczne ponownego użytku, bardziej długotrwałe, przyjazne środowisku i łatwe w naprawie. W ramach tych dążeń postulaty tzw. alternatywnej techniki nie mają zasadniczego wpływu na radykalną zmianę rozwoju technicznego, jednak tu i teraz mobilizują do działań ograniczających i upraszczających systemy techniczne. Ostatecznie o kształtowaniu techniki przystosowanej do przyrody w każdym przypadku powinny rozstrzygać prace uwzględniające konkretne uwarunkowania produkcji i adekwatne do niej rozwiązania techniczne (Ropohl 1985: 179-203).

Wreszcie ekologiczne doskonalenie i stosowanie techniki domaga się coraz wyższej świadomości i roztropności ekologicznej jej użytkowników. Wprawdzie osiągnięcie tego celu uwarunkowane jest organizacją procesu kształcenia i wychowania wszystkich uczestników życia społecznego w warunkach cywilizacji techniczno-technologicznej, to jednak szczególnie odnosi się ono do młodego pokolenia (Lorenz 1986: 171-185). Ten proces rozpoczyna się wraz ze zdobywaniem ogólnego wykształcenia w szkole podstawowej i średniej i powinien być kontynuowany na dalszych etapach kształcenia, aż po szkolnictwo wyższe i kształcenie podyplomowe.

To samo wymaganie odnosi się proporcjonalnie do przedsiębiorców przemysłowych. Muszą oni konsekwentnie dbać o to, aby pracobiorcy byli gruntownie poinformowani o technicznych powiązaniach produkcji z produktem. Media, różnego rodzaju i różnego zasięgu, powinny zajmować się uświadamianiem w tym zakresie $\mathrm{z}$ takim samym zaangażowaniem, z jakim zajmują się innymi dziedzinami kultury (Hubig 1995: 4-35). Dzięki temu wzrastają szanse stworzenia społeczeństwa sprzyjającego ekologicznemu doskonaleniu techniki i technologii. Takie społeczeństwo powinno się organizować wokół idei zrównoważonego rozwoju, zgodnie z którą inicjatywy zdecentralizowane i pluralistyczne współdziałają z inicjatywami kontroli demokratycznej. Należy oczekiwać, że taka kontrola nie popadnie w biurokratyczne skostnienie, lecz będzie stanowiła racjonalną koordynację indywidualnej i społecznej kreatywności. Wtedy też naturalne dążenie do rozwoju techniczno-technologicznego będzie skorelowane $\mathrm{z}$ dążeniem do 
Zbigniew Łepko

utrzymania wysokich standardów bezpieczeństwa ekologicznego aktualnych i nadchodzących pokoleń (Ropohl 1985: 225-245).

\section{Zamiast zakończenia}

Problematyka ekologicznego wartościowania i sytuowania techniki w środowisku naturalnym stanowi ważny punkt odniesienia w filozoficznym sporze o koncepcję przyrody (Łepko 2011: 163-183). Z jednej strony tego sporu znajdują się zwolennicy fizjocentrycznej koncepcji przyrody, zgodnie z którą przyroda stanowi przestrzeń warunkującą istnienie różnych, ale zarazem równouprawnionych podmiotów życia; stanowi pewną całość, poddaną powszechnym prawom. Z drugiej zaś strony znajdują się zwolennicy fizjologicznej koncepcji przyrody, zgodnie z którą przyroda jest całością sprzyjającą, bądź niesprzyjającą zjawisku życia, wielorako w niej zapodmiotowanego; ta koncepcja wskazuje na związek wszystkich istot żywych z przyrodą, wyrażający się $\mathrm{w}$ fizjologicznych procesach wymiany między organizmem a jego otoczeniem.

Zwrócenie uwagi na fizjologiczne doświadczenie przez człowieka procesów metabolizmu przyrody stwarza możliwość ekologicznego wartościowania sposobów i zakresów technicznych ingerencji człowieka w przyrodę. Zgodnie z tym ujęciem odpowiedzialność człowieka nie odnosi się do przyrody jako takiej, lecz do następstw jego działań w przyrodzie. Oznacza to, że odpowiedzialność nie wyraża jedynie pewnego typu relacji człowieka do przyrody, lecz wprost nakłada na niego powinność kultywowania przyrody. Dlatego też główne zadanie filozofii współczesnej należy wiązać z poszukiwaniem kryteriów ekologicznego wartościowania techniki. Przy jej pomocy można bowiem podążać za przeświadczeniem, że koniecznym warunkiem efektywnego korzystania z przyrody jest jej prewencyjna ochrona. Według tej koncepcji technika spełnia rolę pośredniczącą w podejmowaniu przez człowieka kultywacyjnej funkcji wobec samego siebie i przyrody. Technika stanowi tutaj istotne dopełnienie człowieka w jego relacji do przyrody. Gdy więc zwolennicy fizjocentryzmu w technice upatrują zagrożenie dla przyrody, zwolennicy fizjologizmu dostrzega- 
ją związane z techniką możliwości jej kultywowania. Pod warunkiem wszakże, iż zastosowanie techniki będzie się odbywać w perspektywie ekologicznej, co wyraża się w stwierdzeniu, że współczesna technika wymaga ekotechnicznego uzupełnienia. Dlatego też Schäfer - zwolennik fizjologicznej koncepcji przyrody, w odróżnieniu od Jonasa - zwolennika fizjocentrycznej koncepcji przyrody, szansy dla ludzkości nie upatruje w postulacie nowej etyki ekologicznej, lecz w postulacie wartościowanych ekologicznie nowoczesnych form techniki. Tym samym dostrzega możliwość dochowania wierności nowożytnemu projektowi naukowo-technicznego wzbogacania człowieka bez niebezpieczeństwa popadnięcia w błędy popełnione na etapie naiwnej jego realizacji (Schäfer 1993: 267).

Refleksja nad relacją człowieka do przyrody nie musi więc uwzględniać normatywnego charakteru przyrody, jak chcą zwolennicy fizjocentryzmu, lecz ekologiczne wartościowanie różnych sposobów i możliwości kultywowania przyrody, jak chcą zwolennicy fizjologizmu. Ono też zakłada uznanie przyrody za środek w odniesieniu do celu, jakim jest człowiek. Konsekwentnie też pojęcie kultury Schäfer wiąże nierozdzielnie ze stanowiskiem antropocentrycznym i twierdzi, że „kto domaga się odrzucenia antropocentryzmu, odrzuca tym samym zadanie kultywowania przyrody" (Schäfer 1987: 27-28). Właściwe rozumienie tezy o człowieku jako celu przyrody domaga się jej wzbogacenia o tezę o człowieku jako istocie zdolnej do wartościowania w zakresie doboru środków sprzyjających kultywowaniu przyrody. Związek obu tych tez ujmuje Schäfer zgodnie ze stanowiskiem Kanta wyrażonym w Krytyce władzy sadzenia (Kant 1964: 414-431). Według tego ujęcia człowiek tylko wtedy może być postrzegany jako ostateczny cel przyrody, gdy sam dysponuje możliwością ustalania celów. Ponieważ człowiek może ustalać cele jedynie w obszarze działań obyczajowo-praktycznych, jego pozycja jako „pana i władcy przyrody” nie jest związana z możliwością dysponowania określonymi środkami technicznymi, lecz z moralnością. Pozycja pana i władcy przyrody przysługuje człowiekowi nie dlatego, że ma on władzę podporządkowania sobie przyrody ze względu na arbitralnie ustalane cele, lecz tylko dlatego, że zgodnie z moralnością może on traktować przyrodę jako 
środek do osiągania określonych celów. Relacja człowieka do przyrody jest więc podporządkowana moralności człowieka, który dzięki temu stanowi zasadę odpowiedzialnego opanowania i przezwyciężenia kryzysu ekologicznego (Schäfer 1987: 28).

\section{Bibliografia}

Anders G., 1956, Die Antiquirtheit des Menschen. Über die Seele im Zeitalter der zweiten industriellen Revolution, Verlag C. H. Beck, München; Anders G., 1980, Über die Zerstörung des Lebens im Zeitalter der dritten industriellen Revolution, Verlag C. H. Beck, München.

Brennecke V., 1995, Poser H., Garbe D., Schröter W., Gesellschaftlicher Diskurs Technikbewertung als Aufgabe des Gemeinwesens, Funkkolleg, Studienbrief 6 Studieneinheit 20, Tübingen, 4-48.

Bugl J., Mai M., 1994, Technikbewertung als Aufgabe der Politik, Funkkolleg, Studienbrief 6 - Studieneinheit 18, Tübingen, 4-37.

Drieschner M., 1997, Die Macht der Objektivität, w: Meyer-Abich K. M. (red.), „Vom Baum der Erkenntnis zum Baum des Lebens. Ganzheitliches Denken der Natur in Wissenschaft und Wirtschaft", Verlag C. H. Beck, München, 337-356.

Dusek V., 2011, Wprowadzenie do filozofii techniki, Wydawnictwo WAM, Kraków.

Evans R. I. (red.), 1977, Konrad Lorenz-Gespräche mit Richard I. Evans, ein Briefwechsel mit Donald Campbell und vier Essays, Frankfurt am Main-Berlin-Wien.

Hałaczek B., 1994, Aksjologiczna koncepcja nauki podłożem postulatu etyki uniwersalnej, w: J. Sekuła (red.), „Czy możliwa jest etyka uniwersalna? Materiały Ogólnopolskiej Konferencji Naukowej", WSP, Siedlce, 129-140.

Heidegger M., 1959, Gelassenheit, Neske, Pfullingen.

Hösle V., 1991, Philosophie der ökologischen Krise. Moskauer Vorträge, Verlag C. H. Beck, München.

Hubig Ch., 1995, Technikbewertung in Unternehmen, Funkkolleg, Studienbrief 6 Studieneinheit 19, Tübingen, 4-37.

Hubig Ch., Lenk H., Maring M., 1994, Technikethik aus dem Elfenbeinturm? Forderungen ad die Ethik, Funkkolleg, Studienbrief 2 - Studieneinheit 4, Tübingen, $1-33$.

Jonas H., 1981, Interview: Im Zweifel für die Freiheit, Nachrichten aus Chemie, Technik und Laboratorium 29(1981)1, 434-439.

Jonas H., 1990, Technik, Medizin und Ethik. Zur Praxis des Prinzips Verantwortung, Suhrkamp Verlag, Frankfurt am Main.

Jelden E., 1995, Homo faber: Experten oder Expertensysteme, Funkkolleg, Studienbrief 5 - Studieneinheit 14, Tübingen, 4-34.

Kant I.,1964, Krytyka władzy sądzenia, przekł. J. Gałecki, PWN, Warszawa,.

Kiepas A., 1992, Moralne wyzwania nauki i techniki, Oficyna Wydawnicza „Warszgraf”, Katowice - Warszawa. 
König W., Rapp F., 1994, Optimismus und Pessimismus - Technikbewertung einst und jetzt, Funkkolleg, Studienbrief1 - Studieneinheit 2, Tübingen, 1-38.

Kiepas A., 2006, Etyka jako czynnik ekorozwoju $w$ nauce $i$ technice, Problemy Ekorozwoju, 1(2006)2, 77-86.

Lorenz K., 1986, Regres człowieczeństwa, przekł. A. D. Tauszyńska, Państwowy Instytut Wydawniczy, Warszawa.

Łepko Z., 1998, Spór o testament F. Bacona, Studia Philosophiae Christianae ATK 34(1998)2, 53-74.

Łepko Z., 2003, Antropologia kryzysu ekologicznego w świetle współczesnej literatury niemieckiej, Wydawnictwo UKSW, Warszawa.

Łepko Z., 2010a, Ekologiczny postulat nauki dla zrównoważonego rozwoju, Seminare 27(2010), 77-86.

Łepko Z., 2010b, Ekologiczna wymowa dialektyki oświecenia, Studia Ecologiae et Bioethicae 8(2010)2, 121-135.

Łepko Z., 2011, Ekofilozoficzny spór o koncepcję przyrody, Z Zagadnień Filozofii Przyrody i Przyrodoznawstwa 20(2011), 163-183, Wydawnictwo UKSW, Warszawa.

Mieck I.,1967, Luftverunreinigung und Immissionsschutzgesetz in Preußen bis zur Gewerbeordnung 1869, Technikgeschichte (1967)34, 36-78.

Meyer-Abich K. M., 1997, Einführung, w: K. M. Meyer-Abich (red.), „Vom Baum der Erkenntnis zum Baum des Lebens. Ganzheitliches Denken der Natur in Wissenschaft und Wirtschaft“, Verlag C. H. Beck, München, 9-17.

Ropohl G., 1985, Die unvollkommene Technik, Suhrkamp Verlag, Frankfurt am Main, 9-16.

Ropohl G., Hubig Ch., 1994, Technik und Technikbewertung, Funkkolleg, Einführungsbrief, Tübingen,7-17.

Ropohl G., 1996, Technik und Technikbewertung, Suhrkamp Verlag, Frankfurt am Main.

Schäfer L., 1987, Selbstbestimmung und Naturverhältnis des Menschen, w: Schwemmer O. (red.), „Über Natur. Philosophische Beiträge zum Naturverständnis“, Vittorio Klostermann, Franfurt am Main, 15-36.

Schäfer L., 1993, Das Bacon-Projekt. Von der Erkenntnis, Nutzung und Schonung der Natur, Suhrkamp Verlag, Frankfurt am Main.

Weizsäcker von E. U., 1999, Eine neue Politik für die Erde. Die globale Partnerschaft und Ökologie. Herausgegeben von Christoph Quarch, Verlag Hereder, FreiburgBasel-Wien. 


\section{Technology for sustainable development}

\section{SUMMARY}

The technical and technological expansion of man in the nature environment constitutes an important component of ecological debate. The debate shows the initial confrontation of the antagonized positions. The radical critics of technology rejected the then contemporary technical and industrial system and supported "alternative technology", whereas the radical promoters of this system represented a naive belief in the unlimited progress of science and technology.

After some time this debate was enriched by a new idea: sustainable development. It proposes seeking new solutions to the technical and technological presence of man in the natural environemnet. These solutions are expressed by a proportionally balanced synthesis of both positions. The purpose should be to find a way that would be a compromise between the development of technology and the demands of nature. 